\title{
A Educação Alimentar e Nutricional no processo de mudança de comportamento: metodologia e amor
}

\author{
Food and Nutrition Education in the behavior changing process: \\ methodology and love
}

$\mathrm{O}$ comportamento alimentar está caracterizado por procedimentos relacionados às práticas alimentares de grupos humanos, que inclui o que se come, quanto, como, quando, onde e com quem se come, bem como a seleção de alimentos e os aspectos referentes ao preparo da comida. Além disso, está associado a atributos socioculturais, envolvendo aspectos subjetivos individuais e coletivos relacionados ao comer e à comida. Neste contexto, verificamos o quão complexo torna-se o processo de modificação de hábitos e comportamentos alimentares pelo individuo.

A Educação Alimentar e Nutricional (EAN), neste cenário, assume posição importante no intuito de contribuir para que este processo de mudança seja efetivo e com maior êxito. A EAN, segundo o Marco de Referência de Educação Alimentar e Nutricional para as Políticas Públicas, está caracterizada como uma área de conhecimento e de prática constante, transdisciplinar, intersetorial e multiprofissional, que objetiva promover autonomia e ação voluntária em relação aos hábitos alimentares saudáveis. Sugere-se ainda que a prática da educação alimentar e nutricional faça uso de abordagens e recursos educacionais problematizadores e ativos para que possam estabelecer diálogo junto à população, considerando entre outros fatores, as fases do sistema alimentar e as interações e significados que compõem o comportamento alimentar.

O Marco de Referência, assim como o Guia Alimentar para a População Brasileira - em sua nova versão, apresenta subsídios para que os profissionais possam se basear e se apoiar para a articulação e promoção de atividades educativas na área da saúde, da alimentação e nutrição no Brasil, além de utilizá-los como ferramentas de planejamento de programas e outras ações.

Nesta edição da revista Ciência \& Saúde, o artigo intitulado "Educação alimentar e nutricional com universitários residentes de moradia estudantil" aborda este tema e aponta para falta de referências de como trabalhar a EAN entre universitários, bem como para outros tipos de população. Com grandiosidade, faz com que possamos refletir acerca de recursos e técnicas que venham incrementar e colaborar com o processo educativo. Vivenciamos uma época em que a tecnologia e as metodologias se fazem atuantes e exigentes (no sentido de cobrarem conhecimento constante do indivíduo) e que ainda, são fundamentais para que acompanhem nosso ritmo acelerado e também progressivo. Todavia, não podemos esquecer aquele que é o mais nobre dos predicados na formação e na atuação do educador como agente indispensável no processo de mudança: o amor..."Não se pode falar de educação sem amor", nos ensinou Paulo Freire. Quem sabe, seja este o caminho para as devidas respostas e que ainda possamos estabelecer vínculos, dos mais variados sentimentos, de modo que a mudança seja percebida e consolidada por todos os envolvidos.

Desejo uma boa leitura! 